\title{
Atenolol Enhances Growth Hormone Release to Exogenous Growth Hormone-Releasing Hormone but Fails to Alter Spontaneous Nocturnal Growth Hormone Secretion in Boys with Constitutional Delay of Growth ${ }^{1}$
}

\author{
PAUL M. MARTHA, JR., ROBERT M. BLIZZARD, AND ALAN D. ROGOL \\ Departments of Pediatrics [P.M.M., R.M.B., A.D.R.] and Pharmacology [A.D.R.], University of Virginia, School \\ of Medicine, Charlottesville, Virginia 22908
}

\begin{abstract}
We tested the hypothesis that selective $\beta_{1^{-}}$ adrenergic blockade will enhance growth hormone (GH) secretion in boys with constitutional delay of growth in response to both exogenously administered growth hormone-releasing hormone as well as to endogenous GHreleasing hormone pulsations. The study group comprised eight healthy, short, prepubertal boys ranging from $72 / 12$ to $15 \% 12$ yr old with bone ages delayed 15 to 42 months. All had demonstrated GH levels of greater than $10 \mathrm{ng} / \mathrm{ml}$ following a pharmacologic or physiologic stimulus. During two consecutive nights, blood samples were withdrawn every 20 min for GH determination between 2000 and 0800 h. Immediately after each $0800 \mathrm{~h}$ blood withdrawal, $1 \mu \mathrm{g} /$ $\mathrm{kg}$ of GH-releasing hormone (1-40)-OH was administered intravenously to each subject and blood was withdrawn every $15 \mathrm{~min}$ for an additional $2 \mathrm{~h}$. During the day before the second overnight sampling period each subject received atenolol, $25 \mathrm{mg}$ orally, at 1030 and $1600 \mathrm{~h}$ to induce $\beta$ adrenergic blockage. The six subjects in whom $\beta$-adrenergic blockade could be documented had enhanced GH release after GH-releasing hormone administration on the atenolol treatment day both in terms of higher peak GH levels achieved $(p<0.05)$ as well as greater total GH secretion $(3916 \pm 701$ versus $5624 \pm 986 \mathrm{ng} / \mathrm{ml} \cdot \mathrm{min}, p<$ 0.01 ). In contrast, there were no differences in endogenous, unstimulated nocturnal GH pulse characteristics between study and control days. In particular, there were no changes in number of GH pulses, mean 12-h GH concentrations, mean GH pulse height, amount of $\mathbf{G H}$ secreted in pulses, mean interpulse GH levels, or total area under the GH versus time curve. (Pediatr Res 23: 393-397, 1988)
\end{abstract}

\section{Abbreviations}

GH, growth hormone

GHRH, GH-releasing hormone (1-40)-OH

Sm-C, somatomedin-C

BAB, $\beta$-adrenergic blockade

CDG, constitutional delay of growth

Received October 6, 1987; accepted December 9, 1987

Correspondence and requests for reprints Alan D. Rogol, M.D., Ph.D., Department of Pediatrics, Box 386, UVA Medical Center, Charlottesville, VA 22908.

Supported in part by a grant from the U.S. Public Health Service (General Clinical Research Centers) at the University of Virginia and Grants AG04303 to R.M.B. and HD20465 to A.D.R.

${ }^{2}$ Presented in part at the Annual Meeting of the American Pediatric Society, Anaheim CA, 1987
Catecholamines play a central role in the physiologic control of pulsatile GH secretion. Accumulating evidence indicates that these neuromodulators influence the pattern of GHRH and somatotropin release inhibiting hormone (somatostatin) secretion from the hypothalamus into the hypophyseal portal system. Stimulation of central $\alpha$-adrenergic receptors causes GH release, most likely by enhanced GHRH secretion $(1-6)$ whereas $\beta$ adrenergic receptors mediate a GH inhibitory signal, possibly by stimulating somatostatin release (7-14). $\alpha$-Adrenergic agonists are capable of stimulating $\mathrm{GH}$ release in man (1-6), an effect which is diminished by phentolamine $(3,6,7)$. Particularly well studied is clonidine, an $\alpha$-adrenergic agonist. The GH-stimulating properties of clonidine have proven clinically useful both for the diagnosis of growth disorders $(2,4)$ and for stimulation of growth velocity in some children with short stature (15-17). Conversely, administration of $\beta$-adrenergic blocking agents enhances GH release in response to a variety of stimuli including insulin-induced hypoglycemia $(7,11)$, exercise $(10)$, glucagon (13), and GHRH $(8,12,18)$ but fails to cause GH release in the absence of such stimuli $(1,7,8)$.

Recently we showed that administration of the selective $\beta_{1}$ adrenergic antagonist, atenolol, enhanced the $\mathrm{GH}$ response to multiple doses of exogenous GHRH in children with GH deficiency (18). The ability of atenolol to enhance GH release after a single injection of GHRH has also previously been shown in normal adult volunteers (12). Based on the finding that atenolol increases $\mathrm{GH}$ release in response to exogenously administered GHRH, we hypothesized that its administration would also augment $\mathrm{GH}$ release in response to endogenous nocturnal GHRH pulsations. To investigate this hypothesis we studied the acute effects of atenolol administration on the characteristics of nocturnal GH pulses in a group of prepubertal boys with CDG.

\section{MATERIALS AND METHODS}

Study subjects. The study group comprised eight prepubertal boys with a mild to moderate degree of constitutional delay of growth. Clinical and endocrinologic data for these subjects are given in Table 1 . All boys were in otherwise good health and were chosen from our group of patients followed in the University of Virginia Pediatric Endocrinology Clinic. Chronologic ages ranged from $72 / 12$ to $15 \% 12$ yr (mean \pm SEM, $10.3 \pm 1.0$ ) with a mean bone age delay of $25.6 \pm 4.0$ months (range, 15-42 months). Sm-C concentrations determined at $0600 \mathrm{~h}$ on study day 1 , ranged from 0.5 to $1.18 \mathrm{U} / \mathrm{ml}$. All subjects had short stature (height SD scores -1.4 to -2.8 range; $-2.0 \pm 0.2$, mean \pm SEM). Their growth velocities determined over at least 6 
Table 1. Clinical and endocrinologic data on study subjects (prepubertal boys)

\begin{tabular}{|c|c|c|c|c|c|c|c|}
\hline Subject & $\begin{array}{c}\text { Chronologic } \\
\text { age } \\
(\mathrm{yr}) \\
\end{array}$ & $\begin{array}{l}\text { Bone } \\
\text { age } \\
\text { (yr) }\end{array}$ & $\begin{array}{c}\mathrm{Ht} \\
(\mathrm{cm})\end{array}$ & $\begin{array}{c}\mathrm{Ht} \\
\text { SDS* }\end{array}$ & $\begin{array}{l}\text { Growth velocity } \\
(\mathrm{cm} / \mathrm{yr})\end{array}$ & $\begin{array}{c}\text { Growth velocity } \\
\text { SDS* }\end{array}$ & $\begin{array}{c}\mathrm{Sm}-\mathrm{C} \\
(\mathrm{U} / \mathrm{ml})\end{array}$ \\
\hline 1 & $10^{1 / 12}$ & $76 / 12$ & 122.2 & -2.3 & $3.0 \dagger$ & -2.9 & 0.62 \\
\hline 2 & $12^{3 / 12}$ & $11 \% / 12$ & 135.0 & -2.0 & 4.9 & -0.1 & 1.09 \\
\hline 3 & $10^{5 / 12}$ & $7 \% / 12$ & 128.4 & -1.7 & 6.2 & +1.6 & 1.18 \\
\hline 4 & $15 \% 12$ & $11 \% / 12$ & 145.0 & -2.8 & 8.1 & +3.1 & 0.83 \\
\hline 5 & $73 / 12$ & $6 \% 12$ & 110.8 & -2.3 & 6.2 & +0.5 & 1.08 \\
\hline 6 & $72 / 12$ & $56 / 12$ & 112.9 & -1.4 & 5.8 & -0.4 & 0.50 \\
\hline 7 & $9^{7 / 12}$ & $76 / 12$ & 123.8 & -1.7 & 5.0 & -0.3 & 0.64 \\
\hline 8 & $10^{1 \%} / 12$ & $96 / 12$ & 129.2 & -1.9 & 5.0 & -0.1 & 1.10 \\
\hline
\end{tabular}

* SDS (SD scores) based on chronologic age.

$\dagger$ Growth velocity determined over only 4 months in this subject. The velocities in others were determined over at least 6 months.

months were all within 2 SD for bone age (19) with the exception of subject 1 . Subject 1 had a growth velocity that appeared to be normal at the time of study based on a measurement from his private pediatrician. However, during 4 months of measurements in our clinic his growth velocity was only $3.0 \mathrm{~cm} / \mathrm{yr}$. He failed to return for all subsequent appointments after the 4-month measurement so we do not have growth data at 6 months or later.

All subjects achieved serum GH levels of more than $10 \mathrm{ng} / \mathrm{ml}$ in response to a standard pharmacologic or physiologic stimulus. A complete blood count with differential, erythrocyte sedimentation rate, serum chemistry profile, and liver function tests were obtained and judged acceptable for age in all subjects. An ECG was performed and was normal in each boy before his participation. Bone ages were determined by the method of Greulich and Pyle (20) by one of us (P.M.M.) from X-rays of the left hand and wrist.

Study design. After obtaining informed consent from a parent and assent from each boy the subjects were admitted to the University of Virginia Clinical Research Center for approximately $48 \mathrm{~h}$. An intravenous catheter was placed in an upper extremity vein at $1900 \mathrm{~h}$ on the first study night. Between 2000 and $0800 \mathrm{~h}$ blood was withdrawn every $20 \mathrm{~min}$ for GH determinations. At $0831 \mathrm{~h}$ an intravenous injection of GHRH (1-40)$\mathrm{OH}$ at a dose of $1 \mu \mathrm{g} / \mathrm{kg}$ was administered to each subject and blood was withdrawn every $15 \mathrm{~min}$ for an additional $2 \mathrm{~h}$ thereafter. Supine and upright blood pressure and pulse were obtained before and immediately after the GH sampling period. However, during the entire $14.5-\mathrm{h}(2000-1030 \mathrm{~h})$ withdrawal period the subjects remained recumbent (with bathroom use as needed) and blood pressure and pulse were monitored hourly.

On the day of the second overnight study, each subject received atenolol in a dose of $25 \mathrm{mg}$ orally at $1030 \mathrm{~h}$ and again at 1600 h. GH sampling and GHRH stimulation then proceeded exactly as described for the first night except that some subjects retained their intravenous catheter from the previous night.

Assays. All serum samples were analyzed in duplicate for GH concentration using Nichols Institute Diagnostic human GH immunoradiometric assay kits (San Juan Capistrano, CA). The assay sensitivity was $0.5 \mathrm{ng} / \mathrm{ml}$ and the inter- and intraassay coefficients of variation at $4.5 \mathrm{ng} / \mathrm{ml}$ were 7.1 and $5.5 \%$. Sm-C determinations were measured by radioimmunoassay as previously described (21).

Pulse analysis. We applied Cluster analysis (22) to the hormone concentration series from all study periods to identify significant excursions (pulses) of hormone concentration. Briefly, Cluster is a computer based pulse detection algorithm which defines a "pulse" as a significant increase followed by a significant decrease in hormone concentration. The program scans the data series in both directions and performs $t$-comparisons between consecutive groups of hormone values ("clusters") to identify all significant increases and decreases. "Significance" is dependent on the variance present within the actual data set. The various $t$ statistics and cluster sizes used are determined by the user in a manner that constrains the false-positive (type I error) detection rate to a desired level.

We chose our parameters to constrain the false-positive detection rate to less than $5 \%$ while minimizing our false-negative (type II error) rate. This was accomplished by analyzing GH concentration data from eight healthy prepubertal subjects (including four who participated in the present study) obtained every 20 min over $24 \mathrm{~h}$ using a variety of cluster sizes and tstatistics known to be associated with a false-positive detection rate of less than $5 \%$ under the conditions present herein (Veldhuis JD, personal communication). The combination of these parameters resulting in the greatest number of pulses detected was, therefore, associated with the lowest false-negative rate. This combination (a one point by one point cluster size and $t$-statistic of 2.32 to test for both significant increases and decreases) was then used for all GH pulse analysis herein.

Mean nocturnal GH concentrations were computed from all $36 \mathrm{GH}$ values between 2000 and $0800 \mathrm{~h}$. Total nocturnal GH secretion is expressed as area under the $\mathrm{GH}$ versus time curve as determined by trapezoidal reconstruction.

Statistical analysis. Comparisons of data regarding GH secretion on the control day and the day atenolol was administered were performed using the paired Student's $t$ test with the exception of peak GH responses to GHRH. For the latter the nonparametric method of Wilcoxan signed rank test was used since the data were not normally distributed. Results are expressed as mean \pm SEM. We accepted statistical significance at a level of $p$ $<0.05$. Data storage and analysis were accomplished in part through use of the University of Virginia GCRC CLINFO laboratory.

\section{RESULTS}

The presence of systemic BAB was assumed when there was loss of a significant tachycardic response to upright posture after atenolol administration. This was documented in six of the eight study subjects (subjects 1-6) (Table 1). We could detect no clinical differences between these six and the two who did not have evidence of BAB at the end of the study. We purposely did not attempt to determine the cardiovascular response to postural changes during the period of blood withdrawal to avoid the possibility that the expected catecholamine release in the presence of BAB might result in GH secretion via unopposed $\alpha$ adrenergic stimulation (23). Thus, we cannot be certain whether subjects 7 and 8 had evidence of BAB earlier in the study period which had waned by the end.

All six subjects who unequivocally achieved BAB showed enhanced $\mathrm{GH}$ release in response to intravenous GHRH on the atenolol treatment day when compared to the control day (Figs. 1 and 2). This enhancement took the form of both higher peak GH levels achieved $(p<0.05)$ and greater total GH secretion during the $2-\mathrm{h}$ post-GHRH sampling period $(3916 \pm 701$ versus
$5624 \pm 986 \mathrm{ng} / \mathrm{ml} \cdot \mathrm{min}, p<0.01)$. There were no differences in 
GH levels during the 90 -min baseline sampling period immediately before the GHRH bolus $(p=0.19)$. Subjects 7 and 8 , who did not have evidence of $\mathrm{BAB}$, did not show augmented $\mathrm{GH}$ release on the atenolol day (data not shown).

In contrast, there were no differences in the pulse characteristics of nocturnal GH secretion between study and control days (Table 2). Specifically, no changes were found in the number of significant increases in $\mathrm{GH}$ concentration (GH pulses), mean 12h GH concentration, mean GH pulse height, amount of $\mathrm{GH}$ secreted in pulses, mean interpulse (trough) $\mathrm{GH}$ levels, or total nocturnal GH secretion. There were no significant side effects of atenolol reported by any of the subjects.

\section{DISCUSSION}

Recent reports have shown that atenolol administration enhances GH release in response to exogenous GHRH in normal

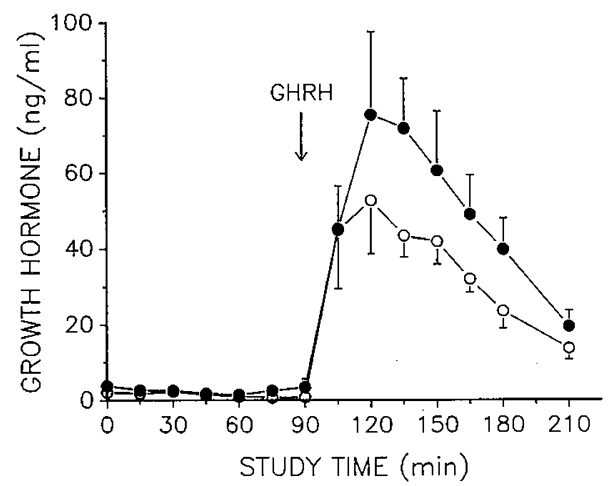

Fig. 1. GH concentration data (mean \pm SEM) from six boys with CDG before (open circles) and after (closed circles) $\mathrm{BAB}$ induced by atenolol administration. Ninety min into the sampling period, a $1 \mu \mathrm{g} / \mathrm{kg}$ intravenous bolus of GHRH (1-40)-OH was administered to each subject. There was significantly more total GH secretion after GHRH (3916 \pm 701 versus $5624 \pm 986 \mathrm{ng} / \mathrm{ml} \cdot \mathrm{min}, p<0.01)$ in the presence of BAB. adults (12) and in children with GH deficiency (18). These observations were a logical extension of earlier studies demonstrating the ability of the nonselective $\beta$-adrenergic antagonist, propranolol, to augment the GH secretory response to a wide variety of stimuli $(7,8,10,11,13)$. Although all studies but one (3) failed to show an effect of $\beta$-adrenergic antagonists on endogenous GH secretion in the absence of other stimuli, none had sampling periods that included a significant number of spontaneous $\mathrm{GH}$ pulses. It is probable that spontaneous $\mathrm{GH}$ pulsations in man, as in the rat $(14,24,25)$, are under dual control of hypothalamic GHRH and somatostatin. We thus hypothesized that atenolol administration would also augment spontaneous GH secretion. A 12-h nocturnal sampling period was chosen to maximize the detection of a number of spontaneous $\mathrm{GH}$ pulses in each subject. It should be noted that our GH values were obtained using an immunoradiometric assay and the absolute values should not be directly compared to those of other inves-

Table 2. Spontaneous nocturnal GH secretory characteristics of six boys with $C D G$ before (control) and after BAB induced by atenolol administration

\begin{tabular}{|c|c|c|c|c|c|c|c|}
\hline Subject & Study day & $\begin{array}{c}\text { Mean } \\
\text { GH concentration } \\
(\mathrm{ng} / \mathrm{ml})\end{array}$ & $\begin{array}{l}\text { Total 12-h } \\
\text { GH secretion } \\
(\mathrm{ng} / \mathrm{ml} \cdot \mathrm{min})\end{array}$ & No. GH pulses & $\begin{array}{c}\text { Mean GH } \\
\text { pulse amplitude } \\
(\mathrm{ng} / \mathrm{ml})\end{array}$ & $\begin{array}{l}\text { Mean pulse area } \\
(\mathrm{ng} / \mathrm{ml} \cdot \mathrm{min})\end{array}$ & $\begin{array}{l}\text { Mean interpulse } \\
\text { GH concentration } \\
(\mathrm{ng} / \mathrm{ml})\end{array}$ \\
\hline \multirow[t]{2}{*}{1} & Control & 10.9 & 7610 & 4 & 28.0 & 1430 & 8.1 \\
\hline & Atenolol & 6.5 & 4510 & 6 & 11.2 & 546 & 2.7 \\
\hline \multirow[t]{2}{*}{2} & Control & 6.2 & 4470 & 6 & 15.6 & 486 & 6.7 \\
\hline & Atenolol & 8.6 & 6210 & 5 & 25.8 & 1208 & 9.6 \\
\hline \multirow[t]{2}{*}{3} & Control & 8.8 & 6170 & 5 & 21.1 & 855 & 8.0 \\
\hline & Atenolol & 4.7 & 3320 & 4 & 12.5 & 568 & 1.6 \\
\hline \multirow[t]{2}{*}{4} & Control & 6.0 & 4310 & 5 & 9.3 & 675 & 4.5 \\
\hline & Atenolol & 4.1 & 2920 & 5 & 7.3 & 342 & 4.5 \\
\hline \multirow[t]{2}{*}{5} & Control & 9.9 & 7070 & 6 & 23.2 & 875 & 7.1 \\
\hline & Atenolol & 6.1 & 4310 & 6 & 16.2 & 565 & 3.9 \\
\hline \multirow[t]{2}{*}{6} & Control & 5.5 & 3960 & 4 & 23.0 & 730 & 4.9 \\
\hline & Atenolol & 5.2 & 3740 & 7 & 10.5 & 401 & 4.3 \\
\hline \multirow{2}{*}{$\begin{array}{l}\text { All subjects (mean } \pm \\
\text { SEM) }\end{array}$} & Control & $7.9 \pm 0.9$ & $5600 \pm 640$ & $5.0 \pm 0.4$ & $20.0 \pm 2.7$ & $842 \pm 131$ & $6.6 \pm 0.6$ \\
\hline & Atenolol & $5.9 \pm 0.7$ & $4170 \pm 480$ & $5.5 \pm 0.4$ & $13.9 \pm 2.7$ & $605 \pm 125$ & $4.4 \pm 1.1$ \\
\hline $\begin{array}{l}\text { (Significance level, } \\
\text { control vs ateno- } \\
\text { lol) }\end{array}$ & & $(p=0.12)$ & $(p=0.13)$ & $(p=0.49)$ & $(p=0.17)$ & $(p=0.32)$ & $(p=0.21)$ \\
\hline
\end{tabular}


tigators determined by polyclonal radioimmunoassays that may detect different epitopes on the $\mathrm{GH}$ molecule.

As expected, atenolol-induced $\beta$-adrenergic blockade enhanced $\mathrm{GH}$ release after exogenous GHRH in our subjects with constitutional delay of growth. Although our data are the first to show augmentated GH release for a selective $\beta_{1}$-adrenergic antagonist in this population, the results are similar to those of Chihara et al. (8) using the nonselective $\beta$-adrenergic blocker, propanolol, in a similar group of children (8) and those of Mauras et al. (12) in normal men. Several lines of evidence indicate that this $\mathrm{GH}$ secretory enhancing effect of $\beta$-adrenoreceptor antagonists is due to their interference with hypothalamic somatostatin activity. First, these agents lack the inherent ability to stimulate GH secretion, although they increase the potency of other GH secretagogues $(7,8,10-13)$. Second, $\beta$-adrenergic agonists have a direct stimulatory effect on GH secretion from rat anterior pituitary cells in vitro (26-29), but do not affect subsequent GHRH-stimulated GH release (Krieg RJ, personal communication). In contrast, isoproterenol infusion to intact rats predominately inhibits subsequent GHRH stimulation, an effect abolished by prior administration of an antiserum to SRIH (Krieg RJ, personal communication). Third, direct application of isoproterenol to slices of rat brain from the amygdaloid complex and preoptic anterior hypothalamic area is capable of stimulating somatostatin release (30). Fourth, $\beta$-adrenergic stimulation causes somatostatin release from pancreatic islets (31).

It has been proposed (24) that the observed ultradian rhythm in $\mathrm{GH}$ secretion in the rat results from a tonic secretion of both GHRH and somatostatin from the hypothalamus into the hypophyseal portal blood with superimposed, reciprocal, periodic secretory surges of the two peptides. This is supported by the findings of Plotsky and Vale (32) using direct measurement of GHRH and somatostatin levels in the hypophyseal portal circulation. In addition, administration of antiserum to somatostatin elevates trough $\mathrm{GH}$ levels in the rat but does not affect $\mathrm{GH}$ pulse amplitude (14). These data indicate that somatostatin is responsible for the $\mathrm{GH}$ trough levels. In this regard our findings are somewhat surprising. If it is true that BAB inhibits somatostatin secretion, and if hypothalamic control of the pulsatile pattern of GH secretion in the human is analogous to the rat, then it would be expected that the interpulse trough levels in our subjects would have been higher on the atenolol treatment day. We did not find such an effect (Table 2). This elevation would also be expected to affect total 12-h GH secretion (as area under the GH versus time curve) and mean 12-h GH concentration but again no differences were found (Table 2). The absence of this anticipated effect may indicate that, in contrast to the rat, hypothalamic somatostatin does not serve a primary role in determining the trough $\mathrm{GH}$ levels in our subjects. It is also possible that if we had studied a full 24-h period an effect of atenolol would have emerged. Alternatively, it may be that due to inter- and intraassay variability as well as variability among this small group of subjects we were unable to detect such changes with certainty even if they existed (type II error).

Our results indicate that, in contrast to $\alpha$-adrenergic agonists (15-17), $\beta$-adrenergic antagonists may not have growth promoting therapeutic potential when used alone in children with constitutional delay of growth although only a full therapeutic trial would answer this question with certainty. However, as we have previously suggested (18) they may be useful as adjunctive therapy in combination with other agents, such as GHRH, which stimulate endogenous $\mathrm{GH}$ release.

Acknowledgments. The authors extend special thanks to Dr. Michael $O$. Thorner for making this study possible. In addition we are indebted to Suzan Pezzoli for help with study coordination; Sandra Jackson and her nursing staff at the Clinical Research Center where the studies took place; Ginger Bauler, Anthony Amos, Catherine Cassada, and Fotini Beziriannidis for technical assistance; Leslie Powell for her excellent help with the manuscript preparation; and Donald Kaiser and David Boyd for assistance with data handling and analysis using the University of Virginia CLINFO system.

\section{REFERENCES}

1. Blackard WG, Hubbell GJ 1970 Stimulatory effect of exogenous catecholamines on plasma $\mathrm{HGH}$ concentrations in the presence of beta adrenergic blockade. Metabolism 19:547-552

2. Gil-Ad I, Topper E, Laron Z 1979 Oral clonidine as a growth hormone stimulation test. Lancet 2:278-279

3. Imura H, Kato Y, Ikeda M, Morimoto M, Yawata M 1971 Effect of adrenergicblocking or -stimulating agents on plasma growth hormone, immunoreactive insulin, and blood free fatty acid levels in man. J Clin Invest 50:1069-1079

4. Lanes R, Hurtado E 1982 Oral clonidine-an effective growth hormonereleasing agent in prepubertal subjects. J Pediatr 100:710-714

5. Lee PA, Thompson RG, Blizzard RM 1974 Relationship of the adrenergic nervous system and growth hormone release in normal adults and children with various growth disorders. Metabolism 23:595-601

6. Massara F, Camanni F 1972 Effect of various adrenergic receptor stimulating and blocking agents on human growth hormone secretion. $J$ Endocrinol 54:195-206

7. Blackard WG, Heidingsfelder SA 1968 Adrenergic receptor control mechanism for growth hormone secretion. J Clin Invest 47:1407-1414

8. Chihara K, Kodama H, Kaji H, Kita T, Kashio Y, Okimura Y, Abe H, Fujita T 1985 Augmentation by propranolol of growth hormone-releasing hormone-(1-44)- $\mathrm{NH}_{2}$-induced growth hormone release in normal short and normal children. J Clin Endocrinol Metab 61:229-233

9. Chihara K, Minamitani N, Kaji H, Kodama H, Kita T, Fujita T 1984 Noradrenergic modulation of human pancreatic growth hormone-releasing factor (hpGHRF 1-44)-induced growth hormone release in conscious male rabbits: involvement of endogenous somatostatin. Endocrinology 1 14:14021406

10. Hansen AP 1971 The effect of adrenergic receptor blockade on the exerciseinduced serum growth hormone rise in normals and juvenile diabetics. $\mathbf{J}$ Clin Endocrinol 33:807-812

11. Imura H, Nakai Y, Kato Y, Yoshimoto Y, Moridera K 1974 Propranololinsulin stimulation test in the diagnosis of growth hormone deficiency. Horm Metab Res 6:343-346

12. Mauras N, Blizzard RM, Thorner MO, Rogol AD 1987 Selective $\beta_{1}$-adrenergic receptor blockade with atenolol enhances growth hormone releasing hormone and mediated growth hormone release in man. Metabolism 36:369372

13. Mitchell ML, Suvunrungsi P, Sawin CT 1971 Effect of propranolol on the response of serum growth hormone to glucagon. J Clin Endocrinol Metab 32:470-475

14. Terry LC, Martin JB 1981 The effects of lateral hypothalamic-medial forebrain stimulation and somatostatin antiserum on pulsatile growth hormone secretion in freely behaving rats: evidence for a dual regulatory mechanism. Endocrinology 109:622-627

15. Castro-Magaña M, Angulo M, Fuentes B, Castelar ME, Cañas A, Espinoza $B$ 1986 Effect of prolonged clonidine administration on growth hormone concentrations and rate of linear growth in children with constitutional growth delay. J Pediatr 109:784-787

16. Loche S, Pintor C, Puggioni R, Pellini C, Cella SG, Locatelli V, Müller EE 1986 Treatment of short stature with clonidine: stimulatory effect in children with constitutional growth delay (CGD). Program and Abstracts, 68th Annual Meeting of The Endocrine Society, Bethesda, MD, p 217(abstr 744)

17. Pintor C, Cella SG, Corda R, Locatelli V, Puggioni R, Loche S, Müller EE 1985 Clonidine accelerates growth in children with impaired growth hormone secretion. Lancet 1:1482-1485

18. Martha PM, Blizzard RM, Pezzoli S, Thorner MO, Rogol AD 1987 Treatment with atenolol increases the growth hormone $(\mathrm{GH})$ response to exogenous growth hormone releasing hormone (GHRH) but fails to augment endogenous GH secretion in non-GH deficient short boys. Pediatr Res 21:250A(abstr)

19. Tanner JM, Davies PW 1985 Clinical longitudinal standards for height and height velocity for North American children. J Pediatr 107:317-329

20. Greulich WW, Pyle SI 1959 Radiographic Atlas of Skeletal Development of the Hand and Wrist. Stanford University Press, Stanford

21. Thorner MO, Reschke J, Chitwood J, Rogol AD, Furlanetto R, Rivier J, Vale W, Blizzard RM 1985 Acceleration of growth in two children treated with human growth hormone-releasing factor. N Engl J Med, 312:4-9

22. Veldhuis JD, Johnson ML 1986 Cluster analysis: a simple, versatile, and robust algorithm for endocrine pulse detection. Am J Physiol 250:E486-E493

23. Parra A, Schultz RB, Foley Jr, TP, Blizzard RM 1970 Influence of epinephrinepropranolol infusions on growth hormone release in normal and hypopituitary subjects. J Clin Endocrinol Metab 30:134-137

24. Tannenbaum GS, Ling N 1984 The interrelationship of growth hormone $(\mathrm{GH})$-releasing factor and somatostatin in generation of the ultradian rhythm of GH secretion. Endocrinology 115:1952-1957

25. Wehrenberg WB, Brazeau P, Luben R, Böhlen P, Guillemin R 1982 Inhibition of the pulsatile secretion of growth hormone by monoclonal antibodies to the hypothalamic growth hormone releasing factor (GRF). Endocrinology $111: 2147-2148$ 
26. Krieg RJ Jr, Thorner MO, Evans WS 1986 Sex differences in $\beta$-adrenergic stimulation of growth hormone secretion in vitro. Endocrinology 119:13391342

27. Perkins SN, Evans WS, Thorner MO, Cronin MJ 1983 Beta-adrenergic stimulation of growth hormone release from perifused rat anterior pituitary cells. Neuroendocrinology 37:473-475

28. Perkins SN, Evans WS, Thorner MO, Gibbs DM, Cronin MJ $1985 \beta$-adrenergic binding and secretory response of the anterior pituitary. Endocrinology 117:1818-1825

29. Swennen $L$ Baes M Denef C 1985 Beta-adrenergic stimulation of $3^{\prime}, 5^{\prime}$ monophosphate (c-AMP) accumulation and of prolactin and growth hor- mone secretion in rat anterior pituitary cell cultures. Neuroendocrinology 40:72-77

30. Epelbaum J, Tapia-Arancibia L, Kordon C 1981 Noradrenaline stimulates somatostatin release from incubated slices of the amygdala and the hypothalamic preoptic area. Brain Res 215:393-397

31. Samols E, Weir GC, Ramseur R, Day JA, Patel YC 1978 Modulation of pancreatic somatostatin by adrenergic and cholinergic agonism and by hyperand hypoglycemic sulfonamides. Metabolism 27:1219-1221

32. Plotsky PM, Vale W 1985 Patterns of growth hormone-releasing factor and somatostatin secretion into the hypophysial-portal circulation of the rat. Science 230:461-463

\section{Announcement}

\section{The Thyroid Foundation of America, Inc.}

Since incorporating in 1984, we have become an effective non-profit educational organization for patients, health professionals, and the general public. Our goals are:

To provide education and support for thyroid patients and health professionals.

To increase public awareness about thyroid problems.

To raise and distribute funds for thyroid research.

Let us help your patients understand their thyroid dysfunction. Our members can receive:

Your Thyroid: A Home Reference. The new paperback edition providing comprehensive information for patients and their families.

The Bridge, our newsletter with articles on key topics such as Chernobyl, Thyroid Nodules, TSH-IRMA, Goiter, and Thyroid Eye Problems, as well as notices about meetings, new books and Foundation news.

Brochures for patients on topics such as Hypothyroidism, Hyperthyroidism, Childhood Neck Irradiation, Thyroid Disease in Pregnancy, Newborn Screening, Thyroid Nodules, and more.

Bibliographies of reference materials on thyroid problems.

We invite you to encourage your patients to join us and learn more about their problems and join as a Health-Professional (\$25) and receive additional patient and membership materials for your office.

Help us to help others! Write to: The Thyroid Foundation of America, Inc., Box J- ACC 630, Massachusetts General Hospital, Boston, MA 02114. 